optimal atherectomy trial (BOAT): 6 months angiography and 1 year clinical follow-up. Circulation 1996, 94(suppl I):I2543.

8 Suzuki T, Kato O, Fujita T, Ueno K, Takase S, Jujii K, et al, for the ABACAS Investigators. Initial and long-term results of the adjunctive balloon angioplasty following coronary atherectomy study (ABACAS) [abstract]. $\mathcal{F} A m$ Coll Cardiol 1997;29(suppl A):68A

9 Moussa I, Moses J, Di Mario C, King T, Reimers B, Colombo A. Immediate and short-term results of the pilot phase of stenting after optimal lesion debulking "The SOLD Trial" [abstract]. $尹$ Am Coll Cardiol 1997; 29(suppl A):415A.

10 Bramucci E, Angoli L, Merlini PA, Barberis P, Kubica J, Laudisa ML, et al. Acute results of adjunct stent following directional coronary atherectomy [abstract]. $7 \mathrm{Am}$ Coll Cardiol 1997;29(suppl A):415A

11 Garratt KN, Holmes DR Jr, Bell MR, Bresnahan JF, Kaufmann UP, Vlietstra RE, et al. Restenosis after direcKaufmann UP, Nietstra RE, et al. Restenosis after direcmary atheromatous and restenosis lesions and influence of subintimal tissue resection. $\mathcal{F} \mathrm{Am}$ Coll Cardiol 1990;16: of subintima

12 de Vrey E, Mintz GS, Kimura T, Nobuyoshi M, Popma JJ, Mehlman $\mathrm{MD}$, et al. Arterial remodeling after directional coronary atherectomy: a volumetric analysis from the serial ultrasound restenosis (SURE) Trial [abstract]. $\mathcal{f} A m$ Coll Cardiol 1997;29(suppl A):280A.

13 Colombo A, Itoh A, Maiello L, Blengino S, Di Mario C,
Zampieri $\mathrm{P}$, et al. Coronary stent implantation in aortoostial lesions: immediate and follow-up results [abstract]. f Am Coll Cardiol 1996;27(suppl A):253A.

14 Colombo A, Maillo L, Itoh A, Hall P, Di Mario C,

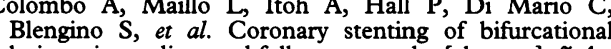
lesions: immediate and follow-up results [abstract]. $\mathcal{F} \mathrm{Am}$ Coll Cardiol 1996;27(suppl A):277A.

15 Sirnes PA, Golf S, Myreng Y, Molstad P, Emanuelsson H, Albertsson $\mathrm{P}$, et al. Stenting in chronic coronary occlusion (SICCO): a randomized, controlled trial of adding stent implantation after successful angioplasty. $\mathcal{F} \mathrm{Am} \mathrm{Col}$ Cardiol 1996;28:1444-51.

16 Honda Y, Yock CA, Hermiller JB, Fitzgerald PJ, Yock PG. Longitudinal redistribution of plaque is an important mechanism for lumen expansion in stenting. $\mathcal{f} \mathrm{Am} \mathrm{Coll}$ Cardiol 1997;29(suppl A):281A.

17 Legrand V, Serruys PW, Emanuelsson H, Fajadet J, Haude M, Klugmann S, et al. Benestent-II trial-final results of visit I: a 15-day follow-up [abstract]. $\mathcal{F} \mathrm{Am}$ Coll Cardiol visit I: a 15-day follow-up

18 Lablanche JM, Danchin N, Grollier G, Bonnet JL, Bedssa $\mathbf{M}$, Vahanian A, et al. Factors predictive of restenosis M, Vahanian A, et al. Factors predictive of restenosis aspirin. $\mathcal{F} \mathrm{Am}$ Coll Cardiol 1996;94(suppl I):1498.

19 Yokoi H, Nobuyoshi M, Nosaka H, Kimura T, Yokoi H, Hamasaki $\mathrm{N}$, et al. Coronary stenting for long lesions (lesion length $>20 \mathrm{~mm}$ ) in native coronary arteries: comparison of three different types of stent. F Am Coll Cardiol 1996;94(suppl I):I685.

\title{
If directional coronary atherectomy is useful then why is it not used more often?
}

\author{
Mazhar Khan
}

Directional coronary atherectomy (DCA) was developed to overcome the limitations of balloon angioplasty. However, three well controlled randomised trials have questioned the use of directional atherectomy. ${ }^{1-3}$ The Coronary Angioplasty Versus Atherectomy Trial (CAVEAT) and the Canadian Coronary Atherectomy Trial (CCAT) were the first published trials comparing the two techniques. The design of the trials was such that post-procedural dilatation was strongly discouraged in the atherectomy arm. Intravascular ultrasound has shown that $60-75 \%$ of the final lumen is created by atheroma removal and the remainder by stretching the external wall of the artery. ${ }^{4}$ In view of the benefit of a large post-procedure lumen in reducing restenosis, the use of balloon angioplasty following successful yet suboptimal ( $>15 \%$ residual stenosis) atherectomy is common practice when additional cuts may be unsafe. ${ }^{56}$ The high residual stenosis in CAVEAT and CCAT $(30 \%$ and $26 \%$, respectively) resulted mainly from avoidance of adjunctive balloon angioplasty. The full potential of atherectomy was therefore not realised. It is not the device itself but its ability to provide a larger lumen that may reduce the risk of restenosis. ${ }^{?}$

\section{Is directional atherectomy useful?}

DCA is useful for lesions unfavourable to angioplasty - for example, ostial, bifurcation, eccentric, and shelf-like lesions. ${ }^{8}$ CAVEAT I and CCAT trials, however, did not confirm that DCA was superior for such lesions. ${ }^{9}$ Although larger luminal gain with reduced residual stenosis was achieved despite the use of first generation devices, the long term outcome was similar. The initial gains were at the expense of complications, mainly non- $Q$ wave infarction.

Newer GTO and short window catheters with flexible nosecones are clearly superior to the first generation devices for bifurcation and ostial lesions. The mechanism of luminal enlargement includes sequential excision of tissue that might otherwise be displaced into the branch ostium during balloon angioplasty, while stent placement may cause adjacent vessel compromise or "stent jail". The new ultrasound guided atherectomy catheter is another advance and will allow safe and aggressive debulking with greater precision. Debulking before stenting is an interesting concept in device synergy. It may lead to safer and easier stent deployment. It may result in a larger acute lumen without the need for high pressure inflation. ${ }^{10}$

\section{Regional Medical The Royal Victoria Hospital, Grosvenor Road, Belfast
BT12 6BA, UK}


Why is atherectomy not done more often? The results of three randomised trials showed no long term clinical benefit with atherectomy. ${ }^{1-3}$ The higher incidence of composite end points including myocardial infarction and acute abrupt closure has made DCA an unfavourable tool. It is of limited value for calcified lesions. The large, rigid guide catheter and the cutting device carry a substantial risk in an inexperienced hand. Inappropriate placement of the guiding catheter may result in ostial dissection. Serious femoral vascular complications may occur because of the larger groin puncture. DCA is a difficult, time consuming, and demanding procedure; it requires a long learning curve and regular use is necessary to maintain skill. DCA has become less attractive with the increasing availability of stents, the majority of which can be deployed using $6 \mathrm{~F}$ catheters. Ticlopidine instead of warfarin has allowed stenting to be carried out with fewer complications thus reducing length of hospital stay and overall costs. Stenting has thus largely replaced DCA for many complex lesions. DCA should be reserved for the treatment of lesions such as proximal bulky, eccentric, ostial, and bifurcation lesions. It will continue to remain a unique research tool for obtaining specimens of human coronary atheroma.
1 Topol EJ, Leya F, Pinkerton CA, Whitlow PL, Hofling B, Simonton CA. A comparison of directional atherectomy with coronary angioplasty in patients with coronary artery with coronary angioplasty in patients with coronary artery 329:221-7.

2 Adelman AG, Cohen EA, Kimball BP, Bonan R, Ricci DR, Webb JG, et al. A comparison of directional atherectomy with balloon angioplasty for lesions of the left anterio descending coronary artery. $N$ Engl f Med 1993;329: 228-33.

3 Holmes DR, Topol EJ, Califf RM, Berdan LG, Leya F, Berger PB, et al. A multicentre, randomized trial of coronary angioplasty versus directional atherectomy for patients with saphenous vein bypass graft lesions. Circulation 1995; 91:1966-74.

4 Nakamura S, Mahon DJ, Leung CY, Maheswaran B, Gutfinger DE, Yang J, et al. Intracoronary ultrasound imaging before and after directional coronary atherectomy: in vitro and clinical observations. Am Heart $f$ 1995;129: in vitro

5 Simonton CA, Leon MB, Kuntz RE, Popma JJ, Hinohara T, Bersin RM, et al. Acute and late clinical and angiographic results of directional atherectomy in the optimal atherectomy restenosis study (OARS). Circulation 1995;92:I545.

6 Baim DS, Kuntz RE, Sharma SK, Fortuna R, Feldman R Senerchia $\mathrm{C}$, et al. Acute results of the randomized phase of the balloon versus optimal atherectomy trial (BOAT) Circulation 1995;92:I544.

7 Umans VA, Kean D, Foley D, Boersman E, Melkert R, Serruys PW. Optimal use of directional atherectomy is required to ensure longterm benefit: a study with matched procedural outcome after atherectomy and angioplasty. $f$ Am Coll Cardiol 1994;24:1652-9.

8 Hofling B, Gonschior P, Simpson L, Bauriedel G, Nerlich A. Efficacy of directional atherectomy in cases unsuitable for percutaneous transluminal coronary angioplasty (PTCA) and after unsuccessful PTCA. Am Heart 7 1992;124:341-8.

9 Holmes DR, Topol EJ, Adelman AG, Cohen EA, Califf RM. Randomized trial of directional coronary atherectomy: implications for clinical practice and future investigation. $\mathcal{f}$ Am Coll Cardiol 1994;24:431-9.

10 Mintz GS, Pichard AD, Dussaillant GR, Satler LF, Wong SC, Walsh CL et al. Acute results of adjunct stents following directional atherectomy. Circulation 1995;92:I328. 